DIGITALCOMMONS @WAYNESTATE-
Michigan Journal of Counseling: Research, Theory and Practice

Volume 36 | Issue 2

Article 3

9-1-2009

\title{
Victims of Domestic Violence and Front-Line Workers: A Helping Paradigm
}

Scott W. Peters

Texas A \& M University at San Antonio, scott.peters@tamuk.edu

Heather C. Trepal

University of Texas at San Antonio

Sabina M. de Vries

University of Texas at San Antonio

Sally W. Day

University of Texas at San Antonio

Christopher Leeth

University of Texas at San Antonio

Follow this and additional works at: https://digitalcommons.wayne.edu/mijoc

\section{Recommended Citation}

Peters, S. W., Trepal, H. C., de Vries, S. M., Day, S. W., \& Leeth, C. (2009). Victims of Domestic Violence and Front-Line Workers: A Helping Paradigm, Michigan Journal of Counseling, 36(2), 8-16. doi:10.22237/mijoc/1251763320

This Article is brought to you for free and open access by the Open Access Journals at DigitalCommons@WayneState. It has been accepted for inclusion in Michigan Journal of Counseling: Research, Theory and Practice by an authorized editor of DigitalCommons@WayneState. 


\section{Victims of Domestic}

\section{Violence and}

\section{Front-Line Workers:}

\section{A Helping Paradigm}

Scott W. Peters, Ph.D.

Texas A \& M University

at San-Antonio

Heather C. Trepal, Ph.D.

Sabina M. de Vries, EPC

Sally W. Day, Ph.D.

Christopher Leeth, M.A.

University of Texas at San Antonio

Author Note

Scott W. Peters is with the Department of Counseling and Guidance, in the College of Education at Texas A \& M University, San Antonio. Heather

C. Trepal, Sabina M. de Vries-Kell, Sally W. Day, and Christopher Leeth, all with the Department of Counseling, Educational Psychology, Adult \& Higher Education at The University of Texas at San Antonio. Correspondence concerning this article should be addressed to Scott W. Peters, TAMUSA- 1450 Gillette Blvd. San Antonio, TX 78224 (e-mail:scott.peters@tamuk.edu).

Victims of domestic violence present a challenge to law enforcement and emergency room personnel. The authors propose a helping approach to assist these professionals. This paradigm is composed of: active and empathetic listening, acceptance without judgment, identifying victims' strengths, honoring victims as experts, and the process of leaving an abusive relationship.

Key Words: domestic violence, law enforcement personnel, emergency room personnel omestic violence is a national health problem and involves virtually every sector of society, regardless of ethnicity, social status, religion, sexual orientation, or gender (Caetano, Field, Ramisetty-Mikler, \& McGrath, 2005; Durose, Harlow, \& Lagen, 2005; Shaver, Lavendosky, Dubay, Basu, \& Jenei, 2005). It may include physical, emotional, psychological, and sexual aspects (Carlson, 2005; Dutton, Kaltman, Goodman, Weinfurt, \& Vankos, 2005; Sackett \& Saunders, 1999). Annually, more than 1.3 million women and 800,000 men are victims of domestic violence (Tjaden \& Thonnes, 2000). However, these statistics only reflect victims who self-reported; it has been suggested that the numbers of victims who do not report are far greater (Felson, Ackerman, \& Gallagher, 2005; Fugate, Landis, Riorden, Naureckas, \& Engel, 2005; Szinovacz \& Egley, 1995).

Often, by the time victims present at counselors' offices, some time has passed since the precipitating domestic violence incident. Many of these clients have already encountered law enforcement and emergency room personnel. Research has indicated victims encounter health care providers and social workers with limited knowledge about domestic violence. Moreover, these professionals may express negative attitudes (e.g., viewing the victim as weak or at fault) towards victims (Shields, Baer, Leininger, Marlow, \& DeKeyser, 1998). Thus, counselors may play an important role in educating professionals who are the first point of contact for many domestic violence victims.

This article briefly presents an overview of domestic violence. Next, a description of the role of front-line workers, specifically law enforcement and emergency room personnel will be discussed. Finally, a helping paradigm is recommended that counselors can use to work with front-line workers from a consultee-centered perspective.

\section{Domestic Violence}

Terms such as family violence, intimate partner violence, interpersonal violence, and spousal abuse have all been used when referring to domestic violence. "Domestic violence constitutes the willful intimidation, assault, battery, sexual assault or other abusive behavior perpetrated by one family member, household member, 
or intimate partner against another" (The National Center for Victims of Crime (NCVC), (2008). For this article, we will use the NCVC definition when referring to domestic violence.

An essential feature of domestic violence is Walker's Cycle of Violence (COV), (1979). Walker identified a general pattern involving how domestic violence repeats within relationships. The COV is comprised of (a) the tension-building phase, (b) the acute battering incident, and (c) the honeymoon phase. During the tensionbuilding phase, strain builds within the couple. There may be verbal, emotional, or physical abuse. Once the tension reaches a crescendo, the acute battering incident occurs. Following the incident, the couple moves into the honeymoon phase. Abusers realize they have gone too far, apologize, and promise the battering will never happen again. Victims become drawn back into the relationship by abusers' sincere apology and behavior. The honeymoon phase fades, and the couple moves into the tension-building phase to begin the cycle again. The COV may help front-line workers to understand the reasons why victims may stay with abusive partners in spite of the dangers.

\section{Those Impacted by Domestic Violence}

Walker (1979) described battered women as those who are repeatedly subjected to any forceful physical or psychological behavior by men with the goal of controlling them without regard for women's personal rights. Battered women may include wives or those in any form of intimate relationships with men. While we recognize that this definition is limited to women, it is still one of the most insightful descriptions. This definition can be expanded to include gay, lesbian, bisexual and transgendered (GLBT) individuals, as well as men.

The majority of literature on domestic violence focuses on female victimization. This may stem from the traditional feminist perspective, which found battering to be a strictly masculine behavior (Younglove, Kerr, \& Vitello, 2002). We also found existing literature is limited related to GLBT relationship abuse. Furthermore, there is far less research in the area of battered men (Cook, 1997). Nonetheless, it is important to recognize that these populations can and do struggle with domestic violence (Cook, 1997; Younglove, Kerr, \& Vitello, 2002).

\section{Front-Line Workers and Domestic Violence Victims}

\section{Law Enforcement Personnel}

Law enforcement personnel are charged with a tremendous responsibility: that of protecting the nation's citizenry. They respond to a variety of situations, including domestic violence. It is difficult to obtain an accurate number of domestic violence calls. However, it has been suggested that a significant number of calls received by police across the country involve domestic violence (Van Hasselt \& Malcolm, 2005). Research also indicated law enforcement personnel generally dislike responding to domestic violence calls (Buzawa \& Buzawa, 1993; Van Hasselt \& Malcom, 2005). Answering domestic violence calls often can be potentially dangerous due to the emotionally volatile nature of the situation. In addition, based on our experience, many times victims do not want to file charges. One reason is that many victims we encountered have had generally negative experiences with law enforcement, having been derided for not pressing charges or for not leaving their abuser. This is supported by Stephens and Sinden (2000) who found that many times when the police did respond, victims were treated as though they were to blame or they even deserved the abuse.

Many cities and municipalities have trainings, workshops, and in-services to assist law enforcement personnel in addressing domestic violence. These programs are both welcomed and necessary. However, law enforcement personnel are not taught about the interrelationship between domestic violence and the systems which oppress and marginalize victims (Huisman, Martinez, \& Wilson, 2005). We propose a more humanistic, empowering, and less stigmatizing perspective when addressing those affected by domestic violence.

\section{Emergency Room Personnel}

Many victims of domestic violence suffer injuries; some are serious enough to require emergency room treatment (Chambliss, Bay, \& Jones, 1995; Guth \& Pachter, 2000; Henry, Roth, \& Gleis, 1992). The Bureau of Justice Statistics (1994) published a special report which found that almost 1.5 million people in the United States were treated for possible interpersonal violence. The National Center for Posttraumatic Stress Disorder (2008) reported that approximately 35\% of all women seen in U.S. emergency rooms were treated for injuries secondary to domestic violence.

Michigan Journal of Counseling • 36:2 • Fall-Winter 2009 
Furthermore, research has suggested the large numbers of victims of domestic violence place a strain on an already overburdened healthcare system (Shields, Baer, Leininger, Marlow, \& DeKeyser, 1998).

Nurses and physicians are often the first individuals victims of domestic violence come into contact with following an abusive incident. As with law enforcement, emergency room personnel are charged with the responsibility of helping those in need. Reid and Glasser (1997) found that physicians generally recognize that addressing victims of domestic violence is important. However, fewer than half felt it was a significant issue with their patients. Furthermore, research has suggested many residents felt their competence to address victims of domestic violence was substandard (Miller, Coonrod, Brady, Moffitt, \& Bay, 2004; Roush, 2009). Emergency rooms utilize a triage method of treatment which means the more serious the illness or injury, the higher the priority and the quicker patients are seen. The authors contend that victims of domestic violence, unless they are seriously injured, are not seen quickly by emergency room personnel. Then, once seen, they may not be given much consideration. As with law enforcement personnel, those staffing emergency rooms may have a negative view of the victims. Victimization may be seen as self-reinforcing, the fault of the victim, or may not be considered within the healthcare professionals' responsibilities (Garimella, Plichta, Houseman, \& Garzon, 2000). In addition, some victims will selfidentify, but some may not. Counselors with knowledge working with victims of domestic violence may be able to provide consultation to these front-line workers.

\section{The Need for a Helping Paradigm}

Consulting, specifically consultee-centered consultation, involves the consultant helping a consultee with a problem involving a client (Caplan, 1970; Caplan \& Caplan, 1993; Knotek \& Sandoval, 2003). A literature review revealed consultee-centered consultation programs related to medical and law enforcement professionals working with domestic violence victims involved risk prevention, referral to community resources, and legal intervention (Corcoran \& Cawood, 2003; Felson, Ackerman, \& Gallagher, 2005; Huisman, Martinez, \& Wilson, 2005; Kernic \& Bonomi, 2007; McCaw, Bauer, Berman, Mooney, \& Holmberg, 2002; Rhodes, Gordon, \& Zelman, 1996). Consultees, in the proposed helping paradigm, include law enforcement and emergency room personnel. Serving as consultants, counselors would be able to utilize their skills to assist the consultees in working with domestic violence victims. The proposed paradigm begins with the assumption that the victim needs, first and foremost, the opportunity to be heard. Counselors, with the combined knowledge of issues related to behaviors of domestic violence victims, the power of abusers, active listening skills and empathy may play an important role in consulting with front-line workers.

Domestic violence victims may encounter polarized behaviors of both law enforcement and emergency room personnel. At one end of the spectrum victims are perceived as incapable of change. At the other end victims are treated as if they deserved the abuse, since they stayed with their abusers. Neither stance taken by front-line workers is helpful or empowering. An approach to victims of domestic violence that is humanistic, positivistic, and empowering is strongly recommended. Concomitantly, the recommended paradigm may assist the consultees by decreasing frustration and fatigue when working with domestic violence victims.

The advantages of the consultee-centered approach are that it strives to create an equal relationship between consultee and consultant, downplays the status of the consultant, and values the knowledge and role of the consultee with the ultimate goal of improving their effectiveness in working with the client (Knotek \& Sandoval, 2003). This approach allows the relationship between front-line workers and victims to be nonthreatening. In addition, this approach provides an adjunct to interventions that are already in place. This approach is designed to improve the consultees' knowledge and understanding of and effectiveness in working with domestic violence cases.

The importance of allowing victims to tell their stories has been well documented (Davis, 2002; Draucker, 2003; Moe, 2007; Roush, 2009). Furthermore, when victims are ready to tell their stories, someone needs to be ready to hear it. Moe conducted a qualitative study of 19 battered women. This study examined how these victims' perceived help from several sources, including law enforcement and emergency room personnel. Several women reported being quite prepared to disclose their abuse, yet were either not asked or simply dismissed. Consider the following comment from one of the participants: "I called the police all the time at first . . . and then I just said, forget it. They're not helping me." 
(p. 686). Other women reported that emergency room personnel simply treated their injuries, discharging them only to return to the abusive partner without affording an opportunity to disclose their abusive situations. When victims are allowed to tell their stories, they reveal among many positive attributes, strength, determination, and confidence (Draucker). These studies demonstrate that victims of domestic violence are ready, willing, and quite able to tell their stories as early as when they are seen by emergency personnel. It should be noted that the recommended approach is not intended to replace counseling which the authors strongly encourage for all victims of domestic violence. The approach is meant to help victims at a time when they are often vulnerable, yet are also open to telling their stories.

\section{Components of the Helping Approach}

Rolland and Walsh (2005) used a systemic approach in working with health professionals and their patients. Originally developed by Doherty and Baird (1983), and supported by Hathaway, Willis, and Zimmer (2002), the model advocates supportive and empathetic listening, normalizing, and being attentive to feelings. The recommended approach advances this model and supports these ideas as potentially empowering to victims, while simultaneously reducing frustration and fatigue on the part of the front-line workers.

As counselors working with victims of domestic violence, we can attest to the desire to help; to be actively engaged in bringing about change. Front-line workers are no different. However, the recommended approach focuses on being less active in trying to change situations or individuals. This approach allows victims to simply tell their stories. Allowing victims to tell their stories can be a profound way to help and can be powerful in the healing process (Hathaway, Willis, \& Zimmer, 2002; Lempert, 1994; Nabi \& Homer, 2001; Towns \& Adams, 2000). While we primarily addressed women, the proposed approach asserts all victims of domestic violence would benefit from being encouraged to tell their stories. Also, it is important to have an understanding of how leaving an abusive relationship is not a simple matter, rather it involves a process. The recommended approach contains the following components: (a) active and empathetic listening, (b) acceptance without judgment, (c) identifying victims' strengths, (d) honoring victims as experts, and (e) understanding leaving as a process.

\section{Active Listening and Empathy}

For almost anyone, being listened to demonstrates that someone cares, that the person is important, and that what they say means something (Hathaway, Willis, \& Zimmer, 2002). This is even more important to victims of domestic violence who have often been silenced and oppressed (Bograd, 2005). Moreover, Stephens and Sinden (2000) found that a significant concern of domestic violence victims was that the police did not even take time to listen to them. The simple act of listening to another person can be profound and conveys what the person says is important and that one is interested (Freedman \& Combs, 1996; Hackney \& Cormier, 2001). Active listening and empathy can send a powerful message of understanding and caring to victims following abusive incidents. Kirschenbaum and Jourdan (2005) found empathy a vital component in therapy that can facilitate change. Consider the following example:

Victim: I can't stop shaking. This has happened before but it was never this bad.

Front-line responder: (leaning forward, making eye contact with victim) You sound really scared (or confused) and we are here to help.

This message can be conveyed by using open-ended questions, responses that indicate interest (such as "um hmm" and head nodding), the accurate reflection of a victim's feelings, and basic nonverbal cues such as leaning in and maintaining eye contact with victims when they are speaking.

\section{Acceptance Without Judgment}

Acceptance and understanding of the victims'story and situation may facilitate positive change and movement away from the unhealthy aspects of their relationships (Kirschenbaum \& Henderson, 1989). Victims may have been criticized by others in their lives for their playing some role in the abuse, or derided for staying in abusive relationships (Stephens \& Sinden, 2000). Having frontline workers simply accept victims may be a welcomed response. Additionally, unconditional acceptance may provide opportunities for victims to further open up and disclose more about the abuse. Acceptance has been reported as helpful for many clients within therapeutic settings (Kirschenbaum \& Henderson, 1989; Lietaer, 1992).

Many victims of domestic violence have been judged, 
often times negatively (Stephens \& Sinden, 2000). Victims are judged for staying and for allowing themselves to be victimized, and of course, judged by abusers. When front-line workers are nonjudgmental, they are further conveying acceptance for victims. In addition, front-line workers need to suspend their own opinions of victims' situations and be able to convey that while engaged with them. Counselors can play a key role in teaching frontline workers about ways to engage in non-judgmental conversations regarding domestic violence. Consider the following examples:

Victim: I don't know why she did this to me. I can't believe it happened and that I'm here in the emergency room. She loves me. I know it.

Front-line responder: (leaning forward, making eye contact with victim) It sounds like she (or your partner) is very important to you.

\section{OR}

Front-line responder: (leaning forward, making eye contact with victim). You sound very upset and unsure of your situation.

Instead of making a statement about the extent of the victim's injuries, placing blame on the victim, or alluding to the future of the relationship, the responders above simply suspended their judgment and focused on listening to victims and conveying respect and attention.

\section{Identifying Victims'Strengths}

In urgent and emergent occurrences of domestic violence, it is often easy (and understandable) to focus on the weaknesses and vulnerabilities inherent with many victims. It brings about a desire to rescue and protect victims. However, these victims have already been perceived as weak by their abusers. Therefore, it is important to find and focus on strengths and assets that victims' possess.

Clients, regardless of their complex situations, have strengths that may be identified and these can be the basis for empowerment (DeJong \& Miller, 1995; Greene, Lee, \& Hoffpauir, 2005; Greene, Lee, Trask, \& think? domestic

had to use

trying to

artner, to

prevent the violence, and

to survive. They may not

react to their feelings as they

are immobilized by their

fears (Peterman \& Dixon,

2003). Peterman and Dixon

suggested counselors allow

victims of domestic violence

to direct counseling sessions,

thereby modeling for victims

how to effectively direct

(1)
Rheinscheld, 1996, 2005). Finding strengths, however minimal, can have profound effects on victims. Counseling approaches such as Solution-Focused counseling and Narrative Therapy place emphasis on client strengths as part of the therapeutic process (Anderson \& Goolishian, 1992, 1997). The following are examples of finding strengths:

Front-line responder: You are here and are talking with us about this very challenging incident you are facing.

Front-line responder: It seems it takes a lot of courage to make this move to get help. What do you

By identifying victims' strengths, front-line workers may begin to move them away from victim roles, thereby further empowering them.

\section{Victims as Experts}

Victims of domestic violence have had to use all of their energy trying to understand their partner, to prevent the violence, and to survive. They may not react to their feelings as they are immobilized by their fears (Peterman \& Dixon, 2003). Peterman and Dixon suggested counselors allow victims of domestic violence to direct counseling sessions, thereby modeling for victims how to effectively direct their lives. Consider the following examples:

Front-line responder: Tell me more about your situation with your partner. You are the expert on your relationship and I don't want to make any assumptions.

Front-line responder: Through your experience, you seem to have a unique knowledge. Would you like to tell me more?

Additionally, Anderson and Goolishian (1992, 1997) emphasized the importance of honoring clients as experts. When front-line workers take the stance of acknowledging victims as experts, it conveys respect for the victims' position and assists them in gaining control of their lives. For victims of domestic violence, it may be a welcome change and for front-line workers, a novel approach. 


\section{The Process of Leaving an Abusive Relationship}

One of the most frustrating issues for helpers is the rate at which domestic violence victims return to abusive relationships. One facet of domestic violence that is not readily understood is that leaving an abusive relationship is a process. Experience indicates that many victims of abuse will return to abusers several times. What is important for front-line workers to understand is that victims may leave an abusive relationship at some point in the future.

One theory that attempts to explain how victims are able to leave abusive relationships is the Stages of Unbonding model (Allen, 1997). In this multi-stage model, victims first begin to be concerned how leaving may impact their abusers. Secondly, victims become anxious they might not be able to make it on their own once they leave abusive relationships. In the third stage, victims exercise their newly gained abilities to observe the abusive relationship more objectively. Often times, in this stage there may be confusion over still loving their abusive partners while clearly understanding the abusive patterns and wanting to heal. The last stage is marked by a desire to regain a sense of self that does not include their abusive partners. Based on our experience, victims of domestic violence may come in contact with front-line workers at any of these stages. Having a basic understanding of some of the patterns encountered in abusive relationships may assist frontline personnel with being able to carry out other facets of the recommended approach: specifically active listening, acceptance without judgment, and identifying victims' strengths.

Allen's (1997) model provides front-line workers valuable information. It affords them evidence that victims can and do successfully extricate themselves from domestically violent relationships. In addition, front-line workers may be less fatigued when intervening with this population. Front-line workers may understand that leaving a relationship does not always happen quickly. Finally, this in turn may increase the victim's level of trust with front-line workers.

\section{Conclusion}

Law enforcement and emergency room personnel are often the first people victims of domestic violence come into contact with following an abusive incident. The authors described a simple, straightforward consultation approach that can be used by these professionals. It is comprised of: (a) active and empathetic listening, (b) acceptance without judgment, (c) identifying victim's strengths, (d) honoring victims as experts, and (e) understanding leaving as a process. These areas are all very familiar to counselors who work with victims of domestic violence and were derived from basic counseling and domestic violence literature. The recommended approach can be taught quickly by counselors who have a background in domestic violence and knowledge of counseling theories. Moreover, it can be taught almost anywhere, such as a local police station or as an in-service or continuing education workshop.

In combination with general information about domestic violence, therecommended approach provides a framework for understanding both domestic violence and its victims. This approach is humanistic, non-pathologizing, and most of all, empowering to victims of domestic violence. Furthermore, it may provide a comforting and stabilizing framework for front-line workers who are all too often faced with intense and emotionally charged situations when working with domestic violence cases. 


\section{References}

Allen, P. G. (1997). A test of validity and reliability of the stages of unbonding scale. (Doctoral Dissertation, University of Cincinnati, 1997). Dissertation Abstract International, 58, 6273.

Anderson, H., \& Goolishian, H. (1992). The client is the expert: A not-knowing approach to therapy. In S. McNamee \& K. J. Gergen (Eds.), Therapy as Social Construction, Newbury Park, CA: Sage.

Anderson, H., \& Goolishian, H. (1997). Conversations, language, and possibilities: A postmodern approach to therapy. New York: Basic Books.

Bograd, M. (2005). Strengthening domestic violence theories: Intersections of race, class, sexual orientation, and gender. In N. J. Sokoloff \& C. Pratt (Eds.), Domestic violence at the margins: Readings on race, class, gender, and culture (pp. 25-38). New Brunswick, NJ: Rutgers University Press.

Buzawa, E., \& Buzawa, C. (1993). The impact of arrest on domestic violence: Introduction. American Behavioral Scientist. $36,558-574$.

Caetano, R., Field, C. A., Ramisetty-Mikler, S., \& McGrath, C. (2005). The 5-year course in intimate partner violence among, white, black, and Hispanic couples in the United States. Journal of Interpersonal Violence. 20, 1039-1048.

Caplan, G. (1970). Theory and practice of mental health consultation. New York: Basic Books.

Caplan, G., \& Caplan, R. B. (1993). Mental health consultation and collaboration. San Francisco: Josey-Bass.

Carlson, B.E. (2005). The most important things learned about violence and trauma in the past 20 years. Journal of Interpersonal Violence, 20, 119-126.

Chambliss, L. R., Bay, R. C., \& Jones, R. F. (1995). Domestic violence: An educational imperative? American Journal of Obstetrical Gynecology, 172, 1035-138.

Cook, P. W. (1997). Abused men. Westport, CT: Praeger Publishers.

Corcoran, M. H., \& Cawood, J. S. (2003). Violence assessment and intervention: The practitioner's handbook. Boca Raton, FL: CRC Press.

Davis, R. E. (2002). The strongest women: Exploration of the inner resources of abused women. Qualitative Health Research, 12, 1248-1264.

Doherty, W., \& Baird, M. (1983). Family therapy and family medicine: Towards the primary care of families. New York: Guilford Press.

DeJong, P., \& Miller, S. D. (1995). How to interview for client strengths. Social Work. 40, 729-736.

Draucker, C. B. (2003). Unique outcomes of women and men who were abused. Perspective in Psychiatric Care, 39, 7-17.

Durose, M. R., Harlow, C. W., \& Lagen, P. A. (2005). Family violence statistics: Including statistics on stranger and acquaintances. United States Department of Justice. Office of Justice Programs. 1-76.

Dutton, M.A., Kaltman, S., Goodman, L.A., Weinfurt, K., \& Vankos, N. (2005). Patterns of intimate partner violence: Correlates and outcomes. Violence and Victims, 20, 483-497.

Felson, R. B., Ackerman, J. M., \& Gallagher, C. A. (2005). Police intervention and the repeat of domestic assault. Criminology, 43, 563-579.

Freedman, J, \& Combs, G. (1996). Narrative therapy: The social construction of preferred realities. New York: W. W. Norton \& Company.

Fugate, M., Landis, L., Riorden, K., Naureckas, \& Engel, B. (2005). Barriers to domestic violence help seeking: Implications for intervention. Violence Against Women, 11, 290-310.

Garimella, R., Plichta, S. B., Houseman, C, \& Garzon, L. (2000). Physician beliefs about victims of spouse abuse and about the physician role. Journal of Women's Health and Gender-Based Medicine, 9, 405-411. 


\section{References}

Greene, G. J., Lee, M. Y., \& Hoffpauir, S. (2005). The language of empowerment and strength in social work: A constructivist perspective. Families in Society, 86, 267-277.

Greene, G. J., Lee, M. Y., Trask, R., \& Rheinscheld, J. (1996). Client strengths and crisis intervention: A solution-focused approach. Crisis Intervention and Time-Limited Treatment. 3, 43-63.

Greene, G. J., Lee, M. Y., Trask, R., \& Rheinscheld, J. (2005) How to work with client strengths in crisis intervention: A solution-focused approach. In A. R. Roberts (Ed), Crisis intervention handbook: Assessment, treatment, and research (3rd ed), (pp. 64-89). New York: Oxford University Press.

Guth, A. A., \& Pachter, L. (2000). Domestic violence and the trauma surgeon. American Journal of Surgery, 179, $134-140$.

Hackney, H. L., \& Cormier, L. S. (2001). The professional counselor: A process guide to helping (4th ed.). Boston, MA: Allyn and Bacon.

Hathaway, J. E., Willis, G., \& Zimmer, B. (2002). Listening to survivors' voices: Addressing partner abuse in the health care setting. Violence Against Women, 8, 687-719.

Henry, S. L., Roth, M., \& Gleis, M. H. (1992). Domestic violence- The medical community’s legal duty. Journal of Kentucky Medical Association, 90, 162-169.

Highlights in Minority Health (2004). What is the Burden of Interpersonal Violence in the United States? Centers for Disease Control. Retrieved October 13, 2005, from http:/www.cdc.gov/omh/Highlights/2004/HOct04.htm.

Huisman, K. Martinez, J., \& Wilson, C. (2005). Training police officers on domestic violence and racism: Challenges and strategies. Violence Against Women, 11, 792-821.

Kernic, M. A. \& Bonomi, A, E. (2007). Female victims of domestic violence: Which victims do police refer to crisis intervention? Violence and Victims, 22(4), 463-473.

Kirschenbaum, H., \& Henderson, V. L. (1989). The Carl Rogers reader. Boston, MA: Houghton-Mifflin Company.

Kirschenbaum, H., \& Jourdan, A. (2005). The current status of carl rogers and the person-centered approach. Psychotherapy: Theory, Research, Practice, Training, 42, 37-51.

Knotek, S. E. \& Sandoval, J. (2003). Current research in consultee-centered consultation. Journal of Educational and Psychological Consultation, 14, 243-250.

Lempert, L. B. (1994). A narrative analysis of abuse: Connecting the personal, the rhetorical, and the structural. Journal of Contemporary Ethnography, 22, 411- 441.

Lietaer, G. (1992). Helping and hindering processes in client-centered/experiential psychotherapy: A content analysis of client and therapist postsession perceptions. In S.G.

Toukmanian \& D. L. Rennie (Eds.), Psychotherapy process research: Paradigmatic and narrative approaches (pp. 134-162). Thousand Oaks, CA: Sage Publications, Inc.

McCaw, B., Bauer, H. M., Berman, W. H., Mooney, L. \& Holmberg, M. (2002). Women referred for on-site domestic violence services in a managed care organization. Women and Health (32)2/3, 23-35.

Miller, A. W., Coonrod, D. V., Brady, J. M., Moffitt, M. P. , \& Bay, R. C. (2004). Medical students training in domestic violence: A comparison of students entering residency training in 1995 and 2001. Teaching and Learning in Medicine, $16,3-6$.

Moe, A. M. (2007). Silenced voices and structured survival: Battered women's help seeking. Violence Against Women, 13, 676-699.

Nabi, R. L., \& Horner, J. R. (2001). Victims with voices: How abused women conceptualize the problem of spousal abuse and implications for intervention and prevention. Journal of Family Violence, 16, 237-253. 


\section{References}

National Coalition of Anti-Violence Programs (2003). Lesbian, gay, bisexual, and transgender domestic violence: 2003 supplement. Retrieved November 2, 2005, from Bhttp://www.avp.org/publications.htm.

National Center for Posttraumatic Stress Disorder (2008). National center for PTSD fact sheet: What is the prevalence of domestic violence? Retrieved on December 2, 2008 from http://www.ncptsd.va.gov/ncmain/ncdocs/fact_shts/fs_domestic_violence.html

Peterman, L. M., \& Dixon, C. G. (2003). Domestic violence between same-sex partners: Implications for counseling. Journal of Counseling and Development, 81, 40-47.

Reid, S. A., \& Glasser, M. (1997). Primary care physicians' recognition of an attitude towards domestic violence. Academic Medicine, 72, 51-53.

Rhodes, R. M., Gordon, J. B., \& Zelman, A. B. (1996). Comprehensive mental health consultation to a shelter for battered women: Preventive implications. In A. B. Zelman (Ed), Early intervention with high-risk children: Freeing prisoners of circumstance (pp. 293-305). Lanham, MD: Jason Aronson.

Rolland, J. S., \& Walsh, F. (2005). Systemic training for health professionals: The Chicago center for family health approach. Family Process, 44, 283-302.

Roush, K. (2009). No one asked what happened. The American Journal of Nursing, 109, 11- Sackett, L. \& Saunders, D.G. (1999). The impact of different forms of psychological abuse on battered women. Violence and Victims, 14, 197-210.

Shaver, C. A., Lavendosky, A. A., Dubay, S. M., Basu, A., \& Jenei, J. (2005). Domestic violence research: Methodological issues related to a community-based intervention with a vulnerable population. Journal of Applied Biobehavioral Research, 10, 27-38.

Shields, G., Baer, J., Leininger, K., Marlow, J., \& DeKeyser, P. (1998). Interdisciplinary health care and female victims of domestic violence. Social Work and Health Care, 27, 27-47.

Stephens, B. J., \& Sinden, P. G. (2000). Victims' voices: Domestic assault victims' perceptions of police demeanor. Journal of Interpersonal Violence, 15, 534-547.

Szinovacz, M.E., \& Egley, L.C. (1995). Comparing one-partner and couple data on sensitive marital behaviors: The case of marital violence. Journal of Marriage and Family, 57, 995-1010.

The National Center for Victims of Crime (2008). Domestic violence, definition. Retrieved on November 30, 2008 from http://www.ncvc.org/ncve/main.aspx?dbName=DocumentViewer\&DocumentID=32347.

Tjaden, P., \& Thonnes, N. (2000). Prevalence, incidence, and consequences of violence against women: Findings from the national violence against women survey. U.S. Department of Justice; Office of Justice Programs; National Institute of Justice, 1-16. Retrieved on November 30, 2008 from http://www.ojp.usdoj.gov/nij/pubs-sum/183781.htm

Towns, A., \& Adams, P. (2000). "If I really loved him enough, he would be okay": Women's accounts of male partner violence. Violence Against Women, 6, 558-585

United States Department of Justice (1994). Violence-related injuries treated in hospital emergency departments Retrieved October 16, 2005, from http://www.ojp.usdoj.gov/bjs/pub/pdf/vrithed.pdf.

Van Hasselt, V. B., \& Malcolm, A. S. (2005). Special issue on the role of law enforcement in domestic violence. Journal of Family Violence, 20, 1-2.

Walker, L. (1979). The battered woman. New York, NY: Harper and Row.

Younglove, J. A., Kerr, M. G., \& Vitello, C. J. (2002). Law enforcement officers' perceptions of same sex domestic violence: Reason for cautious optimism. Journal of Interpersonal Violence, 17, 760-772. 